Łukasz Jan Berezowski

\title{
POZYCJA I ROLA TŁUMACZA JAKO BIEGŁEGO W POSTĘPOWANIU SĄDOWYM WYBÓR ORZECZNICTWA KRAJOWEGO I UNII EUROPEJSKIEJ
}

\section{The position and role of a translator or an interpreter as a court expert: a selection of Polish and EU case-law decisions}

\begin{abstract}
The following study aims at outlining several fundamental case-law decisions provided for by national [Polish] and EU law relating to the participation of a translator or an interpreter in the judicial proceedings involving foreigners (acting as both defendant or injured party). All quoted rulings issued by common courts, Polish Supreme Court and the European Court of Justice extend applicability of the rules of substantive law in Poland (including criminal procedure code and legislation on the common court regime) with regard to the role and position of a translator or an interpreter. The motivation standing behind those decisions is focused on enabling the party with no command of the language of procedure to act comprehensively before the court as well as to be supplied with adequate assistance guaranteed by both domestic and international law.

Key words: case-law decisions on translators, court interpreting, domestic vs international law regulations, position of the translator in court, rights of foreigners in criminal proceedings

Słowa kluczowe: orzecznictwo dotyczące tłumaczy, przekład sądowy, krajowe a międzynarodowe regulacje prawne dotyczące tłumaczy, pozycja tłumacza w sądzie, prawa cudzoziemca przed sądem w postępowaniu karnym
\end{abstract}

\section{1.Źródła prawa międzynarodowego}

- Konwencja o ochronie praw człowieka i podstawowych wolności sporządzona w Rzymie dnia 4 listopada 1950 r. (Dz.U. z 1993 r. Nr 61, poz. 284)

Art. 6 [Prawo do rzetelnego procesu sądowego]

3. Każdy oskarżony o popetnienie czynu zagrożonego kara ma co najmniej prawo do:

a) niezwłocznego otrzymania szczegółowej informacji w języku dla niego zrozumiatym o istocie i przyczynie skierowanego przeciwko niemu oskarżenia; 
e) korzystania z bezpłatnej pomocy tłumacza, jeżeli nie rozumie lub nie mówi językiem używanym w sądzie.

2. Prawodawstwo krajowe

- Konstytucja Rzeczypospolitej Polskiej z dnia 2 kwietnia 1997 r. (Dz.U. z 1997 r. Nr 78, poz. 483)

Art. 45 [Zasada sprawiedliwego procesu]

1. Każdy ma prawo do sprawiedliwego i jawnego rozpatrzenia sprawy bez nieuzasadnionej zwłoki przez właściwy, niezależny, bezstronny i niezawisty sąd.

2. Wyłączenie jawności rozprawy może nastąić ze względu na moralność, bezpieczeństwo państwa i porządek publiczny oraz ze względu na ochronę życia prywatnego stron lub inny ważny interes prywatny. Wyrok ogłaszany jest publicznie.

Art. 91 [Ratyfikowana umowa i jej pozycja w systemie prawa]

1. Ratyfikowana umowa międzynarodowa, po jej ogtoszeniu w Dzienniku Ustaw Rzeczypospolitej Polskiej, stanowi część krajowego porządku prawnego i jest bezpośrednio stosowana, chyba że jej stosowanie jest uzależnione od wydania ustawy.

2. Umowa międzynarodowa ratyfikowana za uprzednią zgoda wyrażona $w$ ustawie ma pierwszeństwo przed ustawa, jeżeli ustawy tej nie da się pogodzić zumowa.

- Ustawa - Prawo o ustroju sądów powszechnych z dnia 27 lipca 2001 r. (Dz.U. z 2001 r. Nr 98, poz. 1070)

\section{Art. 5.}

\1. Językiem urzędowym przed sądami jest język polski.

\$2. Osoba niewtadająca w wystarczajacym stopniu językiem polskim ma prawo do występowania przed sądem w znanym przez nia języku i bezpłatnego korzystania z pomocy ttumacza.

\$3. O przyznaniu ttumacza osobie, o której mowa w \$2, orzeka sąd wtaściwy do rozpoznania sprawy w pierwszej instancji. Wniosek o przyznanie tlumacza zgtoszony $w$ toku sprawy rozpoznaje sąd tej instancji, w której sprawa się toczy.

- Ustawa Kodeks Postępowania Karnego z dnia 6 czerwca 1997 r. (Dz.U. z 1997 r. Nr 89, poz. 555)

Art. 56a [Obowiązek doręczania tłumaczeń decyzji procesowych]

Art. 60a [Tłumaczenie orzeczenia]

Art. 72 [Prawo do pomocy tlumacza]

Art. 150 [Podpisy uczestników czynności]

Art. 177 [Obowiązki świadka]

Art. 204 [Tłumacz]

Art. 618h [Zwrot zarobku lub dochodu biegłego, thumacza, specjalisty]

Art. 6181 [Tryb przyznania należności dla świadka, biegłego, tłumacza, specjalisty] 


\section{Art. 619 [Tymczasowe wykładanie wydatków, koszty mediacji, koszty tłumacza]}

Art. 56a [Obowiązek doręczania tłumaczeń decyzji procesowych]

Oskarżycielowi positkowemu, który nie włada w wystarczającym stopniu językiem polskim, orzeczenie podlegające zaskarżeniu lub kończące postępowanie doręcza się wraz z tłumaczeniem; za zgoda oskarżyciela positkowego można poprzestać na ogłoszeniu przetlumaczonego orzeczenia kończacego postępowanie, jeżeli nie podlega ono zaskarżeniu.

\section{Art. 60a [Tłumaczenie orzeczenia]}

Oskarżycielowi prywatnemu, który nie włada w wystarczającym stopniu językiem polskim, orzeczenie podlegające zaskarżeniu lub kończące postępowanie doręcza się wraz z tlumaczeniem; za zgoda oskarżyciela prywatnego można poprzestać na ogłoszeniu przetłumaczonego orzeczenia kończącego postępowanie, jeżeli nie podlega ono zaskarżeniu.

\section{Prawodawstwo krajowe versus prawodawstwo Unii Europejskiej}

- Powołane wyżej przepisy mają na celu dostosowanie polskich regulacji prawnych do standardów określonych przez Dyrektywę Parlamentu Europejskiego i Rady 2012/29/UE z dnia 25 października 2012 r., która wyznaczyła minimalne normy w obszarze praw, wsparcia i ochrony ofiar przestępstw i jednocześnie zastąpiła decyzję ramową Rady 2001/220/WSiSW (Dz. Urz. UE L 315 z 14.11.2012, s. 57).

- Ustęp 1 artykułu 3 dyrektywy „Prawo do rozumienia i bycia rozumianym” zobowiązuje kraje Unii Europejskiej do stosowania adekwatnych środków celem niesienia pomocy pokrzywdzonym $\mathrm{w}$ rozumieniu i byciu rozumianym od chwili pierwszej ich styczności z odnośnymi władzami, jak również w razie dalszych koniecznych kontaktów z nimi w trakcie postępowania karnego, także na wypadek udzielania informacji przez wyżej wymienione władze.

- Emanacją dyspozycji przywołanych przepisów jest artykuł 7 dyrektywy „Prawo do tłumaczenia ustnego i pisemnego”. W myśl ustępu 3 kraje Unii Europejskiej zapewniają pokrzywdzonemu, który nie posiada znajomości języka (lub języków) używanego na terenie państwa, w którym dane postępowanie karne się toczy (nie rozumie go i nie mówi nim) - stosownie do jego woli w określonym reżymie prawnym właściwym dla spraw karnych - na złożony wniosek nieodpłatny przekład pisemny na język, będący dlań zrozumiałym, informacji koniecznych do skorzystania z przysługujących mu praw w postępowaniu karnym w takim zakresie, w jakim wyżej wymienione informacje są udostępniane pokrzywdzonym (wgląd do akt sprawy, wykonywanie odpisów dokumentów, zawiadomienie o terminach zaplanowanych czynności/rozpraw etc.).

- W zakres informacji objętych obowiązkiem przekładu wchodzi przynajmniej orzeczenie kończące postępowanie karne wszczęte w związku 
z przestępstwem popełnionym na niekorzyść pokrzywdzonego oraz - również na jego wniosek - uzasadnienie tegoż orzeczenia lub zwięzłe streszczenie tego uzasadnienia, $\mathrm{z}$ wyłączeniem orzeczeń wydanych przez ławę przysięgłych lub objętych klauzulą poufności, wówczas - na mocy prawa krajowego - uzasadnienie takie nie jest przedstawiane.

\section{Art. 72 [Prawo do pomocy tłumacza]}

$\$ 1$. Oskarżony ma prawo do korzystania z bezpłatnej pomocy tłumacza, jeżeli nie wtada $w$ wystarczającym stopniu językiem polskim.

\2. Ttumacza należy wezwać do czynności z udziałem oskarżonego, o którym mowa $w$ \$. Na wniosek oskarżonego lub jego obrońcy tłumacza należy wezwać również $w$ celu porozumienia się oskarżonego z obrońcą $w$ związku z czynnością, do udziału w której oskarżony jest uprawniony.

S 3. Oskarżonemu, o którym mowa $w \$ 1$, postanowienie o przedstawieniu, uzupełnieniu lub zmianie zarzutów, akt oskarżenia oraz orzeczenie podlegające zaskarżeniu lub kończace postępowanie doręcza się wraz z ttumaczeniem; za zgoda oskarżonego można poprzestać na ogłoszeniu przettumaczonego orzeczenia kończacego postępowanie, jeżeli nie podlega ono zaskarżeniu.

Art. 72 k.p.k.: orzecznictwo

Wyrok SN z dnia 22 kwietnia 1970 r., III KR 45/70, OSNKW 1970, nr 11, poz. 150

Polskie prawo procesowe tak $w$ art. 129 S 1 k.p.k. $z 1928$ r., jak i obecnie $w$ art. 159 S 1 k.p.k. [z 1969 r.] przewiduje obligatoryjnie wezwanie ttumacza, jeśli zachodzi potrzeba przestuchania osoby nie władającej językiem polskim. Pojęcie niewtadania językiem polskim, uzasadniajace potrzebęuczestnictwa tłumacza, nie może być zwężone do catkowitej nieznajomości języka przez osobę przestuchiwana.

Warunkiem uzasadniającym potrzebę wezwania tlumacza jest stwierdzenie, że osoba przestuchiwana bądź nie rozumie w stopniu dostatecznym zadawanych jej pytań, bądź też na tle stabej znajomości języka polskiego nie może sformułować myśli odtwarzających przebieg zdarzeń, stanowiących przedmiot przestuchania.

Postanowienie SN z dnia 8 października 2009 r., V KK 99/09, OSNKW 2010, nr 3, poz. 26

Jakkolwiek środek odwoławczy, wniesiony przez stronę przeciwna, od orzeczenia podlegajacego doręczeniu z tlumaczeniem, nie figuruje w katalogu pism procesowych, do jakich doręczenia obliguje treść przepisu art. 72 \$ 3 k.p.k. to jednak na taka potrzebę wskazuje wzglą na zasadę lojalności procesowej. Zasada ta, analogicznie jak udostępnienie oskarżonemu w znanym mu języku podstawowego dokumentu, jakim jest wyrok, gwarantuje rzetelny przebieg procesu, a ponadto $w$ większym stopniu umożliwia realizację prawa do obrony na dalszym etapie procesu. 
Postanowienie SN z dnia 4 kwietnia 2012 r., III KK 133/11, OSNKW 2012, nr 8, poz. 81

1. Prawo do pomocy tłumacza przystuguje oskarżonemu, który nie wtada w wystarczającym stopniu językiem polskim $w$ zakresie, w jakim jest to konieczne dla zabezpieczenia elementarnych gwarancji procesowych.

2. Nie jest wymagane pisemne przettumaczenie catych akt danej sprawy, a tylko materiatów niezbędnych dla zapewnienia oskarżonemu rzetelnego procesu.

Decyzja ETPCz z dnia 5 stycznia 2010 r., w sprawie nr 13205/07 Diallo v. Szwecja, echr.coe.int

Na mocy artykułu 6 ustęp 3 litera e Konwencji każdej osobie postawionej w stan oskarżenia przysługuje prawo do skorzystania z nieodpłatnej pomocy tłumacza. Ma ono przełożenie nie tylko w odniesieniu do treści wypowiadanych ustnie na posiedzeniu, ale również do dokumentów sporządzonych pisemnie oraz na etapie postępowania przygotowawczego. Innymi słowy oskarżony, który włada językiem używanym na sali sądowej ma prawo do uzyskania nieodpłatnego przekładu w formie pisemnej lub ustnej wszystkich tych dokumentów lub wypowiedzi z postępowania wszczętego przeciwko niemu, które musi rozumieć, lub które muszą być dostarczone w języku używanym w sądzie, aby zagwarantować mu prawo do rzetelnego procesu.

Przywołana norma nie implikuje jednak, by niezbędne było pisemne przetłumaczenie wszystkich środków dowodowych objętych toczącym się postępowaniem. Wobec tego należy zauważyć, że brzmienie przedmiotowego przepisu odnosi się do "thumacza [ustnego]" [ang. interpreter], a nie do „ttumacza pisemnego” [ang. translator]. Sugeruje ono zatem, że ustna pomoc językowa winna wypełniać zapisy Konwencji. Jednocześnie jednak wspomniana „pomoc tlumacza ustnego” winna mieć taki wymiar, aby oskarżony miał sposobność powzięcia wiedzy w przedmiocie ciążącym na nim zarzutów oraz umożliwić realizację jego praw do obrony, szczególnie w zakresie złożenia przezeń wyjaśnień przed sądem. Dla spełnienia przesłanki praktyczności i skuteczności tegoż prawa, obowiązek właściwych organów władzy nie polega jedynie na wyznaczeniu tłumacza [ustnego], ale również - o ile odnośne władze powezmą wiedzę o specyficznych okolicznościach danej sprawy - rozszerza się on na sprawowanie nadzoru nad adekwatnością dostarczanych usług przekładowych.

Art. 150. [Podpisy uczestnilków czynności]

S $1 . Z$ wyjątkiem protokołu rozprawy lub posiedzenia protokót podpisują osoby biorące udzial w czynności. Przed podpisaniem należy go odczytać i uczynić o tym wzmiankę.

\2. Osoba uczestnicząca $w$ czynności może podpisując protokót zgłosić jednocześnie zarzuty co do jego treści; zarzuty te należy wciagnąć do protokołu wraz $z$ oświadczeniem osoby wykonującej czynność protokołowana. 
Wyrok SA w Krakowie z dnia 2 lipca 2008 r., II AKa 89/08, KZS 2008, z. 10, poz. 41; KZS 2008, z. 10, poz. 42

1. Skoro protokót zeznań śledczych świadka składanych z udziałem ttumacza nie zostat podpisany przez tlumacza jak tego wymaga przepis art. $150 \$ 1$ k.p.k., nie można byto tego protokotu odczytać na rozprawie gtównej.

2. Nietrafny jest zarzut, że w protokołach zeznań świadków nie ma wzmianki, $i \dot{z}$ odczytali te protokoły przed podpisaniem. Po pierwsze - nie mogliby ich odczytać, skoro byli cudzoziemcami, a języka polskiego nie znali i składali zeznania zudziatem tlumacza. Po drugie - formularze protokołów zawieraja wydrukowana wzmianke "odczytano mi - odczytatem osobiście”, wystarczająca do stwierdzenia, że podpisanie protokołu nastapito po stwierdzeniu zgodności zapisów z treścia zeznań.

3. Funkcję ttumacza może wykonywać nie tylko tłumacz przysięgty, ale i każda inna osoba posiadająca odpowiednią znajomość języka (arg. $z$ art. $195 w z w . z$ art. $204 \$ 3$ k.p.k.).

\section{Art. 204 [Tłumacz]}

Należy wezwać tlumacza, jeżeli zachodzi potrzeba przestuchania: pisma,

1) głuchego lub niemego, a nie wystarcza porozumienie się z nim za pomoca

2) osoby nie wtadajacej językiem polskim.

\2. Należy również wezwać tłumacza, jeżeli zachodzi potrzeba przełożenia na język polski pisma sporzadzonego w jezzku obcym lub odwrotnie albo zapoznania strony $z$ treścia przeprowadzanego dowodu.

\$ 3. Do tlumacza stosuje się odpowiednio przepisy dotyczące biegtych.

Art. 197 [Przyrzeczenie biegłego]

\1. Biegly składa przyrzeczenie następującej treści: „Świadomy znaczenia moich stów i odpowiedzialności przed prawem, przyrzekam uroczyście, że powierzone mi obowiązki wykonam z cała sumiennościa i bezstronnościa".

S2. Biegły sądowy powołuje się na przyrzeczenie złożone przy ustanowieniu go w tym charakterze.

S 3. Do biegłego stosuje się odpowiednio przepisy art. 177 obowiązek stawiennictwa i sposoby przestuchania świadka, art. 179-181, art. 187 odbieranie przyrzeczenia od świadka, art. 188 składanie przyrzeczenia przez świadka $\$ 2$ i 4, art. 190 uprzedzenie świadka o odpowiedzialności karnej oraz art. 191 przestuchanieświadka $\$ 1$.

\section{Wnioski}

- Obowiązkiem biegłego tłumacza w postępowaniu sądowym jest zapewnienie oskarżonemu/poszkodowanemu będącemu cudzoziemcem niewładającym językiem polskim prawa do uczciwego procesu, jak również dostarczenie sądowi i stronom postępowania tłumaczenia wypowiedzi ww. cudzoziemca. Nie jest 
zaś rolą tłumacza pełnienie nieokreślonej ustawowo roli obrońcy, psychologa czy pośrednika w kontaktach z rodziną cudzoziemca.

- Aby zapewnić oskarżonemu prawo do rzetelnego procesu, może on skorzystać z pomocy tłumacza także poza czynnościami stricte procesowymi (wizja lokalna, badanie wariografem, konfrontacja, badanie przez lekarza sądowego etc.).

- Tłumacz dokonuje przekładu dokumentów procesowych i wypowiedzi ustnych stanowiących czynności procesowe, a nie calości akt danej sprawy. Nie znajduje bowiem racjonalnego uzasadnienia tłumaczenie całości akt, w tym wezwań, zawiadomień, notatek urzędowych i dokumentów, niezwiązanych z zarzutem postawionym niewładającemu językiem polskim.

- Tłumacz może poprzestać, za zgodą oskarżyciela, na ogłoszeniu przetłumaczonego orzeczenia, ale tylko orzeczenia kończącego postępowanie w sprawie, jeżeli nie podlega ono zaskarżeniu lub gdy ulega ono uprawomocnieniu, a strony nie wnoszą o wydanie pisemnego uzasadnienia.

- Biegu terminu do wniesienia środka odwoławczego przez cudzoziemca niewładającego językiem polskim nie liczy się od doręczenia mu tekstu polskiego orzeczenia, ale dopiero od doręczenia go w tłumaczeniu na język dla niego zrozumiały (postanowienie SA w Krakowie z 20 maja 1999 r., II AKz 126/99, KZS 1999, z. 5, poz. 34; postanowienie SA w Katowicach z 29 października 2003 r., II AKz 919/03, KZS 2004, z. 2, poz. 60).

- Dodatkowo należy podkreślić, że oskarżony niewładający w wystarczającym stopniu językiem polskim nie może zrezygnować z pomocy tłumacza, przepis art. $72 \$ 2$ k.p.k. jest bowiem sformułowany kategorycznie - nakazuje wezwać tłumacza do czynności z udziałem oskarżonego.

\section{Bibliografia}

Dudka K., Paluszkiewicz H., Szumiło-Kulczycka D., Kodeks postępowania karnego. Wybór orzecznictwa z komentarzem, Wolters Kluwer, Warszawa 2015.

Zbiór orzeczeń z zakresu prawa karnego procesowego wraz z komentarzami. Postępowanie przed sądem pierwszej instancji. Casebook, red. D. Kala, C.H. Beck, Warszawa 2013.

Akty prawne

Dyrektywa Parlamentu Europejskiego i Rady 2012/29/UE z dnia 25 października $2012 \mathrm{r}$.

Konstytucja Rzeczypospolitej Polskiej z dnia 2 kwietnia 1997 r. (Dz.U. z 1997 r., Nr 78, poz. 483).

Konwencja o ochronie praw człowieka i podstawowych wolności sporządzona w Rzymie dnia 4 listopada 1950 r. (Dz.U. z 1993 r. Nr 61, poz. 284).

Ustawa - Kodeks postępowania karnego z dnia 6 czerwca 1997 r. (Dz.U. z 1997 r. $\mathrm{Nr} 89$, poz. 555). 
Ustawa - Prawo o ustroju sądów powszechnych z dnia 27 lipca 2001 r. (Dz.U. z 2001 r. $\mathrm{Nr}$ 98, poz. 1070).

\section{Orzecznictwo}

Decyzja ETPCz z dnia 5 stycznia 2010 r., w sprawie nr 13205/07 Diallo v. Szwecja, echr.coe.int

Postanowienie SA w Katowicach z 29 października 2003 r., II AKz 919/03, KZS 2004, z. 2, poz. 60.

Postanowienie SA w Krakowie z 20 maja 1999 r., II AKz 126/99, KZS 1999, z. 5, poz. 34 .

Postanowienie SN z dnia 4 kwietnia 2012 r., III KK 133/11, OSNKW 2012, nr 8, poz. 81.

Postanowienie SN z dnia 8 października 2009 r., V KK 99/09, OSNKW 2010, nr 3, poz. 26.

Wyrok SA w Krakowie z dnia 2 lipca 2008 r., II AKa 89/08, KZS 2008, z. 10, poz. 41; KZS 2008, z. 10, poz. 42.

Wyrok SN z dnia 22 kwietnia 1970 r., III KR 45/70, OSNKW 1970, nr 11, poz. 150. 